ORIGINAL ARTICLE

\title{
Relationship between Maternal Hemoglobin Concentration to the Newborn Cord Blood Hemoglobin and Serum Concentration
}

\author{
SAMREEN FAKEER MUHAMMAD ${ }^{1}$, PARIGUL BALOCH ${ }^{2}$, SHAKEEL AKBAR ${ }^{3}$, SAFIA EWAZ ALI ${ }^{4}$, SHAZIA SAEED ${ }^{5}$, \\ MARYAM SHOAIB ${ }^{6}$ \\ ${ }^{1}$ Senior Registrar, Gynae \& Obs department Bolan Medical University, Quetta \\ ${ }^{2}$ Consultant Obs \& Gyane Department Sheikh Khalifa Bin Zayed Hospital, Quetta \\ ${ }^{3}$ Assistant Professor (General Surgery) Jhalawan Medical College, Khuzdar \\ ${ }^{4}$ Senior Medical Officer, Gynae \& Obs Department, Civil Hospital, Quetta \\ ${ }^{5,6}$ Assistant Professor Gynae \& Obs Department, Civil Hospital, Quetta \\ Corresponding Author: Dr. Samreen Fakeer Muhammad, Email: drsamreensirajbalouch@yahoo.com, Cell No.+92 3312179931
}

\begin{abstract}
Objective: To determine the mean cord blood hemoglobin and ferritin concentration in newborn of anemic mothers.

Study Design: Cross sectional

Place and Duration: Gynae \& Obs department of Dow University Hospital, a tertiary care hospital in Karachi, Pakistan during the period from January, 2018 to July, 2019.

Methodology: A total of 100 anemic pregnant women as per inclusion and exclusion criteria were included in this study. Cord blood sample $(5 \mathrm{ml})$ was obtained by sterile needle puncture immediately after cord clamping. $2 \mathrm{ml}$ will collected in EDTA bottle for full blood count analysis and $3 \mathrm{ml}$ collected in plain bottle for serum ferritin analysis. Final outcome was recorded on approved proforma.

Results: The average age of the patients was $29.33 \pm 3.23$ years. Mean cord blood hemoglobin and ferritin concentration in newborn of anemic mothers was $14.78 \pm 1.62 \mathrm{~g} / \mathrm{dl}$ and $94.10 \pm 67.47 \mathrm{u} / \mathrm{ml}$.

Conclusion: We found that average hemoglobin of the women recruited in our study was $9.59 \pm 0.815 \mathrm{~g} / \mathrm{dl}$ however we could find no correlation between mean cord blood hemoglobin and ferritin concentration in newborn of anemic mothers.

Key Words: Cord blood Hemoglobin, Ferritin, Anemic mothers.
\end{abstract}

\section{INTRODUCTION}

Hemoglobin is a polypeptide protein that is especially adapted for a gas transport to and from lungs. It is comprised of four globin chains, each of which contains an iron containing porphyrin pigment called haem. A single haem molecule contains a ferrous iron (fe+2) to which oxygen reversibly binds (1). Excess iron in the blood is stored, usually in the form of ferritin by protein apoferritin in the liver hepatocytes (2). The cut-off values of blood hemoglobin for pregnant women is $>11 \mathrm{~g} / \mathrm{dl}$ and serum ferritin $>10 \mathrm{ug} / \mathrm{l}$, while the level for neonatal hemoglobin is $>13 \mathrm{~g} / \mathrm{dl}$ and serum ferritin is $>75 \mathrm{ug} / \mathrm{l}$ (3). During pregnancy anemia is labeled when hemoglobin level are $<11 \mathrm{~g} / \mathrm{dl}$. Anemia is one of the most frequent complications related to pregnancy. During this period, the most common type that occursis iron deficiency(4). As part of normal physiology of pregnancy, absorption of dietary iron from the gut is increased, in response to increased iron demand. Despite this adaption, pregnant female still require supplementary iron (5). Low iron store at birth, as well as iron deficiency in infancy adversely affect cognitive, emotional, motor, and neurophysiologic development of the child (4).

The WHO reports that around $35-75 \%$ (56\% on average) of pregnant female in developing countries is anemic, whereas those affected in industrialized nations make up only $18 \%(6)$. The prevalence rates in South Asian countries are as follows: Maldives (55.4\%), Bangladesh (50\%), India (49.7\%), Nepal (42.4\%), Malaysia (35\%), Sri Lanka (34\%) and Iran (21.4\%). (7)

In Pakistan, the prevalence is $48.2 \%$, out of which iron deficiency is the cause of $90.5 \%$ of the anemia (8). It has recently been discovered that $56 \%$ of children under the age of five years are anemic in Pakistan. Children aged between 6 months to 3 years are $60-90 \%$ of affected (9). The mean cord blood hemoglobin concentration and mean serum ferritin concentration was found $12.54 \pm 2.54$ and $7.26 \pm 115.60$ in newborn of anemic pregnant women (3).

As there is high prevalence of anemia in pregnant women in Pakistan. The purpose of the study is to determine the mean cord hemoglobin and serum ferritin in newborn of anemic mother. This study will provide the baseline data which was helpful to develop further statistics and protocol to prevent this deficiency.

\section{MATERIALS AND METHODS}

This cross sectional study was conducted at Gynae \& Obs department of Dow University Hospital, a tertiary care hospital in Karachi, Pakistan during the period from January, 2018 to July, 2019. A total of 100 anemic pregnant women with ages 18 to 40 years were enrolled in this study. Detailed demographics including age, parity, gestational age, education and family income were recorded after taking written informed consent. Gestational age $<36$ week or $>42$ week by last menstrual period (LMP), twin or multiple pregnancies on ultrasound, intrauterine death/stillbirth on ultrasound, maternal age $<18 \mathrm{yr}$ or $>40 y e a r$, and women with parity $>4$ were excluded.

Cord blood sample $(5 \mathrm{ml})$ was obtained by sterile needle puncture immediately after cord clamping. $2 \mathrm{ml}$ will collected in EDTA bottle for full blood count analysis and 
$3 \mathrm{ml}$ collected in plain bottle for serum ferritin analysis. Final outcome was recorded on approved proforma.

Analysis will performed using SPSS version 18.Frequency was calculated for categorical variable like parity. Education Level and family monthly income. Mean and standard deviation will computed for numerical variable like age, $\mathrm{Hb}$ level of mother, $\mathrm{Hb}$ level of newborn and serum ferrritin level in newborn. Stratification with respect of age. Post stratification ANOVA for more than two groups and t-test for two groups was applied. $p$ value $\leq 0.05$ was taken as significant.

\section{RESULTS}

Mean average age of the patients was $29.33 \pm 3.23$ years, mean hemoglobin of the women was $9.59 \pm 0.815 \mathrm{~g} / \mathrm{dl}$. Mean gestational age was $38.26 \pm 1.17$ weeks. Regarding parity of the women, $25 \%$ women had para 1 and $75 \%$ had parity 2 to $4.65 \%$ patients were literate while $35 \%$ were illiterate. $32 \%$ patients had family income $>20000$ rupees, $38 \%$ had 15000 to $20000,25 \%$ had $>10000$ to 15000 and $5 \%$ had $<10000$ rupees. (Table 1 )

Table No 1: Baseline details of all the included patients

\begin{tabular}{|l|l|l|}
\hline Variables & Frequency No. & $\%$ \%age \\
\hline Mean age (yrs) & $29.33 \pm 3.23$ & - \\
\hline Hemoglobin (g/dl) & $9.59 \pm 0.815$ & - \\
\hline Gestational Age (weeks) & $38.26 \pm 1.17$ & - \\
\hline Parity & 25 & $25 \%$ \\
\hline 1 & 75 & $75 \%$ \\
\hline 2 to 4 & 65 & $65 \%$ \\
\hline Education & 35 & $35 \%$ \\
\hline Literate & \multicolumn{2}{|l|}{} \\
\hline Illiterate & 5 & $5 \%$ \\
\hline Family Income & 25 & $25 \%$ \\
\hline$<10000$ & 38 & $38 \%$ \\
\hline 10000 to 15000 & 32 & $32 \%$ \\
\hline 15000 to 20000 &
\end{tabular}

Mean cord blood hemoglobin and ferritin concentration in newborn of anemic mothers was $14.78 \pm 1.62 \mathrm{~g} / \mathrm{dl}$ and $94.10 \pm 67.47 \mathrm{u} / \mathrm{ml}$ as shown in table 2. Comparison mean cord blood hemoglobin and ferritin concentration in newborn among different age groups, and found no significant difference with $p$-value $>0.05$. (Table 3)

Table No 2: Mean Cord Blood Hemoglobin and Ferritin Concentration in Newborn of anemic Mothers

\begin{tabular}{|c|c|c|c|}
\hline \multicolumn{2}{|c|}{ Descriptive Statistics } & \begin{tabular}{|l} 
Cord Blood \\
Hemoglobin \\
$(\mathrm{g} / \mathrm{dl})$
\end{tabular} & $\begin{array}{l}\text { Cord Blood } \\
\text { Ferritin } \\
(\mathrm{u} / \mathrm{ml})\end{array}$ \\
\hline \multicolumn{2}{|l|}{ Mean } & 14.78 & 94.10 \\
\hline \multicolumn{2}{|l|}{ Std. Deviation } & 1.62 & 67.47 \\
\hline \multirow{2}{*}{$\begin{array}{l}95 \% \text { Confidence } \\
\text { Interval for Mean }\end{array}$} & Lower Bound & 14.46 & 80.71 \\
\hline & Upper Bound & 15.10 & 107.49 \\
\hline \multicolumn{2}{|l|}{ Median } & 14.55 & 82.15 \\
\hline \multicolumn{2}{|l|}{ Interquartile Range } & 2.6 & 77.4 \\
\hline \multicolumn{2}{|l|}{ Minimum } & 9.6 & 7.4 \\
\hline \multicolumn{2}{|l|}{ Maximum } & 18.4 & 298 \\
\hline
\end{tabular}

Table No 3: Comparison of Mean Cord Blood Hemoglobin and Ferritin Concentration in Newborn of Anemic Mothers among Different Maternal Age Groups

\begin{tabular}{|l|l|l|l|l|l|}
\hline \multirow{2}{*}{ Variables } & \multicolumn{3}{|l|}{ Age Groups (Years) } & \multirow{2}{*}{ P-Values } \\
\cline { 3 - 6 } & $<=25$ & $\begin{array}{l}26 \quad \text { to } \\
30\end{array}$ & $>30$ & \\
\hline \multirow{2}{*}{$\begin{array}{l}\text { Cord Blood } \\
\text { Hemoglobin } \\
(\mathrm{g} / \mathrm{dl})\end{array}$} & $\mathrm{n}$ & 12 & 57 & 31 & \\
\cline { 2 - 6 } & Mean & 14.79 & 14.81 & 14.7 & \multirow{2}{*}{0.96} \\
\cline { 2 - 6 } & $\begin{array}{l}\text { Std. } \\
\text { Deviation }\end{array}$ & 1.35 & 1.72 & 1.59 & \\
\hline \multirow{2}{*}{$\begin{array}{l}\text { Cord Blood } \\
\text { Ferritin (u/ml) }\end{array}$} & $\mathrm{n}$ & 12 & 57 & 31 & \\
\cline { 2 - 5 } & Mean & 88.93 & 95.17 & 94.13 & 0.95 \\
\cline { 2 - 5 } & $\begin{array}{l}\text { Std. } \\
\text { Deviation }\end{array}$ & 59.56 & 71.88 & 63.74 & \\
\hline
\end{tabular}

\section{DISCUSSION}

Anaemia is a serious problem for women of childbearing age and it can have devastating effects on their babies Anaemia in pregnancy is a major challenge to obstetric care in developing countries where the prevalence rate varies between 33 and $75 \%{ }^{[10-11]}$ when compared with figures from developed countries with a prevalence rate of $14 \% .{ }^{[12]}$ Since the prevalence of anaemia in nonpregnant women in developing countries is also high $(43 \%),{ }^{[13]}$ it is possible that many of these women were already anaemic at the time of conception. Causes of anaemia during pregnancy in developing countries are multi-factorial. This include nutritional deficiencies (iron, folate and vitamin B12), and parasitic diseases such as malaria and hookworm infestation.[14] However, micronutrient deficiency, especially iron deficiency, is believed to be the main underlying cause for anaemia in pregnancy. ${ }^{[15]}$ Whatever the cause, maternal anaemia has adverse consequences on the outcome of pregnancy as anaemia in pregnancies is associated with preterm deliveries, low birth weights, morbidity and perinatal mortality due to the impairment of oxygen delivery to placenta. ${ }^{[16]}$

"Newborn Haematology" recently represented as an area of study that focused in study of umbilical cord blood and its elements in general [17]. The iron content of the newborn infant is an important source of iron for haemoglobin formation in the first few months of life since the iron content of milk is low. At birth, the umbilical cord blood haemoglobin is an important haematological parameter in newborn ${ }^{[18]}$. Haemoglobin and haematocrit values have been used frequently in the diagnosis and followup of the neonatal anemia [19]. White blood cell(WBC) and platelet counts also proven to be helpful in the assessment of neonatal sepsis and the haemostatic status of infant ${ }^{20]}$.

Multi-parity and short birth interval (less than 2 years) between pregnancies created a large demand for iron, which was needed to develop the fetus and placenta. Additional iron was lost with blood at delivery and it can appear maternal anaemia. We found in our study $75 \%$ had parity 2 to 4 , but we found no relationship with age. These findings were consistent with another study by Veghari et al [21]. In contrast, in another study, women with parity $>2$ had higher mean haemoglobin 
concentration than nulliparous ones ${ }^{[22] . ~ I t ~ h a s ~ b e e n ~}$ observed that younger mothers, especially teenage mothers, are prone to iron-deficiency anaemia ${ }^{[23]}$, but in our study we found no relationship with age. We included mothers of age ranges from 18-40 year with mean age $29.33 \pm 3.23$ years.

Many studies, with differing results, have been done on the relationship between maternal and neonatal iron status [24-25]. Rios et al. did not report any significant difference in serum ferritin level in infants of iron-depleted and non-depleted mothers ${ }^{[26]}$. Kelly, MacDonald and McDougall observed a significantly lower ferritin level in cord serum when mothers were iron deficient ${ }^{27]}$. We did not found a significant correlation between maternal and neonatal iron status. Mean cord blood hemoglobin and ferritin concentration in newborn of anemic mothers was $14.78 \pm 1.62 \mathrm{~g} / \mathrm{dl}$ and $94.10 \pm 67.47 \mathrm{u} / \mathrm{ml}$ which is normal according to our operational definition i.e. normal Cord blood hemoglobin is $>13 \mathrm{~g} / \mathrm{dl}$. While serum ferritin level is normal when when newborn serum ferritin is $>75 \mu \mathrm{g} / \mathrm{L}$. In accordance to our results Harthoorn et al, have shown that iron deficiency in mothers during pregnancy dose not influence the fetal iron supply. ${ }^{[28]}$ A study on 20 normal and 6 iron-deficient mothers showed no relationship between the pre-delivery serum ferritin in the two populations of mothers and the serum ferritin of their newborns' cord blood [29]. The explanation for the findings of the present study is may be that serum ferritin and therefore iron stores are only reduced in neonates if maternal iron stores are completely exhausted, and that was not the case in any of current study subjects. In our study the average hemoglobin of the women was $9.59 \pm 0.815 \mathrm{~g} / \mathrm{dl}$.

\section{CONCLUSION}

We found that average hemoglobin of the women recruited in our study was $9.59 \pm 0.815 \mathrm{~g} / \mathrm{dl}$ however we could find no correlation between mean cord blood hemoglobin and ferritin concentration in newborn of anemic mothers.

\section{REFERENCES}

1. Boon NA, Colledge NR, Walker BR, Hunter JAA editor. Blood disorders, Davidson's principle and practice of medicine. $20^{\text {th }}$ edition India Elsevier 2006;1005.

2. Guyton AC, Hall JE. Red Blood Cells.Anemia and Polycythemia, Guyton and Hall textbook of medical physiology. $10^{\text {th }}$ edition: London: WB Saunders company. 2001;387.

3. Adediran A, Gbadegesion A, Adeyemo TA, Akinbami A, Osunkalu V, OgbennaA, et al. Cord blood haemoglobin and ferritin concentration in newborns of anaemic and non-anaemic mother in Lagos,Nigeria. Niger Med J. 2013;54:22-6.

4. Shao N, Lou J, Rao R, Georgieff MK, Kuciroti N, Felt BT,et al Maternal serum ferritin concentration is positively associated with newborn iron stores in women with low ferritin status in late pregnancy.JNutr. 2012;2:2004-9.

5. Baker PN, Jones G, Kean L, Kenny IC, Mcewan A, Mires G,et al Physiological changes in pregnancy, Obstetrics by ten teachers. $19^{\text {th }}$ edition London Hodder education 2011;22.

6. Raza N, Sarwar I, Munazza B, Ayub M, Sulaman M. Assesment of iron defficiency in pregnant women by determining iron status. J. Ayub Med Coll Abbottabad. 2011;23(2):36-40.
7. Noronha JA, Khasawneh EA, Seshan V, Ramasubramaniam S, Raman S. Anaemai in pregnancy consequences and challenges. J South Asian Fed Obstet Gynecol. 2012;4(1):64-70.

8. Akhtar S, Ahmed A, Ahmed A, Ali Z, Riaz M, Ismail T. Iron status of Pakistani population-current issues and strategies. Asia Pac J ClinNutr. 2013;22(3);340-47.

9. Khan E, Hyder SZ, Tondeur MC, Raza S, Khan NA, ZotikinSH,et al. Home fortification with sprinkles to reduce childhood anaemialession learned in North West Frontier Province,Pakistan. Pak J Med Res. 2006;45(2):35-40.

10. Nyuke RB, Letsky EA. Etiology of anaemia in pregnancy in South Malawi. Am J Clin Nutr.2000;72:247-56.

11. Ogunbode O. Anaemia in pregnancy. In: Okonofua F, Odunsi K, editors. Contemporary Obstetrics and Gynaecol for Developing Countries. Benin City Nigeria: Women's Health and Action Research Center; 2003;514-29.

12. Khalafallah AA, Dennis AE. Iron deficiency in pregnancy and postpartum: Pathophysiology and effect of oral versus intravenous iron therapy. J Pregnancy. 2012;2012:630519.

13. ACC/SCN in collaboration with the International Food Policy Research Institute. Geneva: ACC/SCN; 2000. ACC/SCN. The $4^{\text {th }}$ report on the world nutrition situation: Nutrition throughout the life cycle

14. VanderJagt DJ, Brock HS, Melah GS, EL-Nafaty AU, Crossey MJ, Glew $\mathrm{RH}$. Nutritional factors associated with anaemia in pregnant women in Northern Nigeria. J Health PopulNutr. 2007;25:75-81.

15. van den Broek NR, Letsky EA. Aetiology of anaemia in Southern Malawi. Am J Clin Nutr.2000;72:2473-565.

16. Idowu OA, Mafiana CF, Sotiloye D. Anaemia in pregnancy: A survey of pregnant women in Abeokuta, Nigeria. Afr Health Sci. 2005;5:295-9.

17. Elgari MM, WaggiallahHA.Assessment of hematological parameters of neonatal cord blood in anemic and non-anemic mothers. Journal of Clinical and Experimental Research. 2013;1(2).22-25.

18. Qaiser DH, Sandila MP, Omair A, Ghori GM. Correlation of routine haematological parameters between normal maternal blood and the cord blood of healthy newborns in selected hospitals of Karachi. J phys and Surg Pak. 2013;23(2):128-31.

19. Mamoury GH, Hamedy AB, Akhlaghi F. Cord haemoglobin in newborn in correlation with maternal haemoglobin in Northeastern Iran. IJMS. 2003;28(3):166-8.

20. Singla PN, Chand S. Effect of maternal anaemia on the placenta and the newborn infant. ActaPaediatrica. 2008:67(5):645-8.

21. Veghari, GR, Mansourian AR and Marjani AJ. The comparison of the anaemia in pregnant women and non pregnant women in the villages of South- East of Caspian Sea- Gorgan- Iran. J Med Sci. 2007;7:303-6

22. Chandyo RK, Strand TA, Ulvik RJ, Adhikar RK, Ulak M, Dixit H, et al. Prevalence of iron deficiency and anaemia among healthy women of reproductive age in Bhaktapur.Nepal Eur $\mathrm{J}$ Clin Nutr. 2006;1:1-8.

23. King JC. The risk of maternal nutritional depletion and poor outcomes increases in early or closely spaced pregnancies. J nutrition. 2003;133;1732-6S.

24. Jaime-Pérez JC, Herrera-Garza JL, Gómez-Almaguer D. Relationship between gestational iron deficiency andiron deficiency in newborn; erythrocytes. Hematology. 2000;5(3):257-62

25. Vásquez-Molina ME, Corral-Terrazas $M$, Apezteguia MA, Carmona-Sawasky J. Relationship between maternal and neonatal iron stores. Saludpublica de Mexico. 2001;43(5):402-7

26. Rios E. Relationship of maternal and infant iron stores as assessed by determination of plasma ferritin. Pediatrics. 1975; 55(5):694-9.

27. Kelly AM, MacDonald DJ, McDougall AN. Observations on maternal and fetal ferritin concentration at term. British $\mathrm{J}$ Obst and Gynaecol. 1978;85(5):338-43

28. Harthorn EJ, Lindemans J, Langenhurjsen MM: Dose iron deficient erythropoisis in pregnancy influence fetal iron supply? Acta Obstet Gyncol Scand. 2001;80;392-6.

29. Malope BI, MacPhail AP, Alberts M, Hiss DC. The ratio of serum transferrin receptor and serum ferritin in the diagnosis of iron status. Br J Haematol. 2001;115:84-9. 